\title{
Commentary The ethics of CYP2D6 testing for patients considering tamoxifen
} Anne-Renee Hartman ${ }^{1}$ and Paul Helft ${ }^{2}$

\author{
11155 Merrill Street, \#102, Menlo Park, CA 94025, USA \\ 2Indiana University, Division of Hematology/Oncology, 535 Barnhill Drive, RT473, Indianapolis, IN 46202, USA
}

Corresponding author: Paul Helft, phelft@iupui.edu

Published: 13 April 2007

This article is online at http://breast-cancer-research.com/content/9/2/103

(c) 2007 BioMed Central Ltd
Breast Cancer Research 2007, 9:103 (doi:10.1186/bcr1663)

evidence demonstrates that the CYP2D6 gene is an important predictor of tamoxifen efficacy.

The CYP2D6 enzyme is part of the P450 enzyme system and is responsible for metabolizing tamoxifen to its most active form, endoxifen. Humans all inherit two alleles for the CYP2D6 gene, one from each parent. Each allele may be normal (designated ' $w t$ ') or variant type (designated ' $v t$ '). Thus, genotypically, an individual may be homozygous wild type (wt/wt), heterozygous (wt/vt), or homozygous variant $(v t / v t)$. Each of these genotypes may lead to variable metabolism of drugs like tamoxifen. Individuals with CYP2D6 polymorphisms that render the gene product inactive, termed 'poor metabolizers', produce endoxifen at very low levels [2,5]. Approximately $7 \%$ to $10 \%$ of the Caucasian population are poor metabolizers. The evidence presented at ASCO suggests these poor metabolizer patients are at increased risk of breast cancer recurrence because of lack of tamoxifen efficacy resulting from their CYP2D6 genotype. In addition, certain inhibitors of the CYP2D6 enzyme, such as the selective serotonin reuptake inhibitors, which are frequently given to breast cancer patients to combat hot flashes and treat depression, may result in altered tamoxifen activity, and lead to poorer clinical outcomes $[2,4]$.

These extraordinarily important findings have resulted from analyses of only a few hundred patients and are retrospectively derived; however, they may potentially affect many thousands of women worldwide who take adjuvant tamoxifen as part of therapy for breast cancer.

Under what circumstances should patients considering tamoxifen as an adjuvant therapy be tested for CYP2D 6 and under what circumstances should patients taking tamoxifen avoid potent inhibitors of CYP2D6? There is concern over the widespread clinical use of CYP2D6 genotyping to guide decision-making about adjuvant therapies without prospectively validated data and because of the relatively small

$\mathrm{Al}=$ aromotase inhibitor 
number of patients from which the outcomes in tamoxifentreated patients have been derived. The problem with such retrospective data is that it is impossible to exclude the possibility that some factor other than the factor analyzed (in this case, CYP2D6 genotype) may account for or contribute to the imbalance found in the outcomes. Prospective trials can attempt to control for such confounding imbalances through randomization and other techniques. When the potential benefits of a proposed therapy are large, as they are in the case of adjuvant tamoxifen, the standards of validation for a predictive test used to determine whether or not that therapy should be provided must be high. This is true unless there are other, acceptable alternatives that provide similar potential benefits, as in the case for postmenopausal women contemplating tamoxifen as part of their adjuvant hormonal therapy and for women on tamoxifen who are taking selective serotonin reuptake inhibitors, such as paroxetine and fluoxetine, that are potent inhibitors of CYP2D6.

Postmenopausal, hormone-positive breast cancer patients contemplating tamoxifen as part of their adjuvant hormonal therapy have a clear choice between an aromotase inhibitor (Al) for five years or sequencing tamoxifen and an $\mathrm{Al}[6,7]$. Because both alternatives are acceptable and currently widely used in practice, providing postmenopausal women with information about their CYP2D6 genotype will allow them to make an informed choice about their adjuvant hormonal treatment and, most importantly, avoid the potential of taking a therapy that may lack efficacy when there are acceptable alternatives. Because Al treatment provides a benefit of equal if not superior magnitude to tamoxifen in postmenopausal women, poor metabolizers will be able to avoid tamoxifen by taking an $\mathrm{Al}$ and, consequently, decrease their risk of breast cancer recurrence. The Breast Intergroup has tentatively approved a randomized study to further evaluate the role of CYP2D6 status and treatment with an $\mathrm{Al}$ upfront versus tamoxifen followed by an $\mathrm{Al}$ in postmenopausal women.

Pre- and perimenopausal women who are considering taking tamoxifen in an adjuvant setting do not have such alternatives. More prospectively derived outcomes data are needed to confidently extend the recommendation for CYP2D6 genotyping to these patients. Although a reasonable alternative to tamoxifen for these women might be an $\mathrm{Al}$ in addition to ovarian suppression, no randomized trials have demonstrated equivalence between these two alternatives, although the Suppression of Ovarian Function Trial (SOFT) is currently addressing this question [8] In addition, ovarian suppression has undesirable side effects, may affect fertility, and is irreversible if surgical oophorectomy is performed. Thus, in contrast to the situation for postmenopausal patients, proven, equivalent alternatives to tamoxifen do not exist. For these reasons we conclude that CYP2D 6 genotyping should not be routinely performed as a predictive test used to make treatment decisions for pre- and perimenopausal women until we have more definitive data.

\section{Conclusions}

Our ethical responsibility to our patients is to carefully balance risks and benefits in helping them to make decisions. At times, we are in a position of uncertainty with respect to the magnitude of risks as well as benefits. In such cases, especially when the magnitude of potential benefit is large (as it is in the case of tamoxifen) and the magnitude of risk is uncertain, we should err on the side of caution and continue to recommend therapies for which there is strong or definitive evidence. This responsibility can sometimes require waiting until a therapy or test has prospectively proven efficacy before prescribing it to our patients, or until there are proven alternatives available.

\section{Competing interests}

Dr Hartman reports being a medical consultant to DNA Direct, Inc.

\section{References}

1. Stearns V, Johnson MD, Rae JM, Morocho A, Novielli A, Bhargava $P$, Hayes DF, Desta Z, Flockhart DA: Active tamoxifen metabolite plasma concentrations after coadministration of tamoxifen and the selective serotonin reuptake inhibitor paroxetine. $J$ Natl Cancer Inst 2003, 95:1758-1764.

2. Jin Y, Desta Z, Stearns V, Ward B, Ho H, Lee KH, Skaar T, Storniolo AM, Li L, Araba A, et al.: CYP2D6 genotype, antidepressant use, and tamoxifen metabolism during adjuvant breast cancer treatment. J Natl Cancer Inst 2005, 97:30-39.

3. Goetz MP, Rae JM, Suman VJ Safgren SL, Ames MM, Visscher DW, Reynolds C, Couch FJ, Lingle WL, Flockhart DA, et al:: Pharmacogenomic determinants of outcome with tamoxifen therapy: Findings from the randomized North Central Cancer Treatment Group adjuvant breast cancer trial 89-30-52. Breast Cancer Res Treat 2004, Suppl1:88LS35.

4. Knox SK, Ingle JN, Suman VJ, Rae JM, Safgren SL, Ames MM, Visscher DW, Reynolds C, Couch FJ, Lingle WL, Weinshilbourn $\mathrm{RM}$, et al:: The impact of cytochrome P450 2D6 metabolism in women receiving adjuvant tamoxifen. Breast Cancer Res Treat 2007, 101:113-121.

5. Grabinski JL, Smith LS, Chrisholm GB, Drengler R, Rodriguez GI, Lang AS, Katler SP, Garner AM, Fichtel LM: Relationship between CYP2D6 and estrogen receptor alpha polymorphisms on tamoxifen metabolism in adjuvant breast cancer treatment. J Clin Oncol (Meeting Abstracts) 2006, 24:506.

6. National Comprehensive Cancer Network: Clinical Practice Guidelines in Oncology (V.2-2006) [http://www.nccn.org/ professionals/physician_gls/PDF/breast.pdf]

7. Winer EP, Hudis C, Burstein HJ, Wolff AC, Pritchard KI, Ingle JN, Chlebowski RT, Gelber R, Edge SB, Gralow J: American Society of Clinical Oncology technology assessment on the use of aromatase inhibitors as adjuvant therapy for postmenopausal women with hormone receptor-positive breast cancer: status report 2004. J Clin Oncol 2005, 24:619-629.

8. Suppression of Ovarian Function Trial (SOFT): Phase III trial evaluating the role of ovarian function suppression and the role of exemestane as adjuvant therapies for premenopausal women with endocrine responsive breast cancer.

[http://www.cancer.gov/clinicaltrials/ view_clinicaltrials.aspx?version=healthprofessional\&cdrid=318832] 